\title{
New Ionic Liquids with Buffering and Chelating Abilities for Enzyme Engineering
}

\author{
Guangnan $\mathrm{Ou}^{1,2^{*}}$, Biyan $\mathrm{He}^{1,2}$ \\ ${ }^{1}$ College of Food and Biological Engineering, Jimei University, Xiamen, China \\ ${ }^{2}$ Fujian Provincial Key Laboratory of Food Microbiology and Enzyme Engineering, Xiamen, China \\ Email: ^gn ou@jmu.edu.cn
}

How to cite this paper: $\mathrm{Ou}, \mathrm{G} . \mathrm{N}$. and $\mathrm{He}$ B.Y. (2019) New Ionic Liquids with Buffering and Chelating Abilities for Enzyme Engineering. Advances in Bioscience and Biotechnology, 10, 320-330. https://doi.org/10.4236/abb.2019.1010025

Received: September 16, 2019

Accepted: October 20, 2019

Published: October 23, 2019

Copyright (c) 2019 by author(s) and Scientific Research Publishing Inc. This work is licensed under the Creative Commons Attribution International License (CC BY 4.0).

http://creativecommons.org/licenses/by/4.0/

Open Access

\begin{abstract}
Ionic liquids (ILs) with buffering and chelating abilities were designed and synthesized on the basis of ethylenediaminetetraacetic acid (EDTA) for the development of buffered enzymatic IL systems and for enzymatic reaction in heavy metal containing aqueous system. Transesterification activity of Candida antarctica lipase B dissolved in the hydroxyl-functionalized IL was buffer dependent. High activity and outstanding stability was obtained with the buffered enzymatic IL systems for the transesterification. In heavy metal containing aqueous system, EDTA IL buffers as $\mathrm{Hg}^{2+}$ chelators protected horseradish peroxidase (HRP) against $\mathrm{Hg}^{2+}$-induced denaturation and precipitation. Higher $\mathrm{pH}$ favored the protection, while at lower $\mathrm{pH}$ the protection diminished. We can conclude that the new ILs possess both buffering and chelating abilities.
\end{abstract}

\section{Keywords}

Ionic Liquid, EDTA, Buffer, Chelator, Lipase, Peroxidise, Heavy Metal

\section{Introduction}

Enzymes catalyze a wide variety of reactions best in heavy-metal-free aqueous environments and at physiological $\mathrm{pH}$ with exquisite selectivity and stereospecificity [1]. Thus, an appropriate buffer is needed to closely regulate the ionization state of ionizable groups of the enzyme in both aqueous and non-aqueous media. We have synthesized a new class of ionic liquids (ILs) with buffering behaviour that are referred to as IL buffers, which can be used for control of ionization state of enzymes in non-aqueous media [2]. Remarkable buffer dependence of the catalytic activities has been observed in hydrogenation of olefins [2] and selective hydrogenation of unsaturated aldehyde [3] in organic solvents and in 
ILs. Organic solvents are widely used with enzymes to improve the solubility of hydrophobic reactants and/or products and to shift reaction equilibria from hydrolysis toward synthesis [4]-[9]. With the emergence of ILs, the use of ILs as a new type of non-aqueous medium may offer a convenient solution to both the solvent emission and the catalyst recycling problem [5] [9]-[22].

Increasing water contamination by heavy metals has prompted investigations to find ways to clean the environment and also to understand the mechanisms leading to metal toxicity, among which is enzyme inhibition. This inhibition was most often attributed to the reaction of the metal ions with the thiol groups of cysteine residues of the enzyme, resulting in the formation of mercaptides [23] [24].

It was reported that peroxidases are inhibited by heavy metal ions at higher concentrations [25] and $\mathrm{Hg}^{2+}$ ion is listed as the most effective inhibitor [26] [27]. Konyaeva et al. reported that $\mathrm{Hg}^{2+}$ chelators like EDTA can protect hemoglobin against $\mathrm{Hg}^{2+}$-induced denaturation and precipitation [28].

Like most biological buffers in use today, IL buffers were developed only for keeping the $\mathrm{pH}$ of a solution constant, which cannot protect enzymes against metal-induced denaturation and precipitation. We then designed and synthesized new ILs with both buffering and chelating abilities for enzymatic reactions in heavy metal containing aqueous system and in IL system.

\section{Materials and Methods}

\subsection{Materials}

Candida antarctica lipase B (CALB, $10.9 \mathrm{U} \cdot \mathrm{mg}^{-1}$ ), horseradish peroxidase (HRP, $150 \mathrm{U} \cdot \mathrm{mg}^{-1}$ ), bis-tris-propane (BTP), guaiacol and ethyl butyrate were purchased from Sigma-Aldrich. Ethyl butyrate and $n$-butanol were analytical reagents and were dried by $3 \mathrm{~A}$ molecular sieves before use. All other chemicals and reagents were of analytical grade. 1-buthyl-3-methyl-imidazolium chloride ([BMIM]Cl) and 1-(1-hydroxyethyl)-3-methyl-imidazolium tetrafluoroborate ([ $\left.\mathrm{C}_{2} \mathrm{OHMIM}\right]$ $\left.\left[\mathrm{BF}_{4}\right]\right)$ were synthesised according to published procedures [11]. [ $\left.\mathrm{C}_{2} \mathrm{OHMIM}\right]$ $\left[\mathrm{BF}_{4}\right]$ was checked for the absence of chloride and acid. The IL was passed through a neutral alumina column, dried at $50^{\circ} \mathrm{C}$ under reduced pressure for more than $18 \mathrm{~h}$, and stored under dry $\mathrm{N}_{2}$.

The ${ }^{1} \mathrm{H}$ NMR and ${ }^{13} \mathrm{C}$ NMR spectra were obtained on a Brüker AV-400 Fourier transform NMR spectrometer. ${ }^{1} \mathrm{H}$ NMR spectra were referenced to tetramethylsilane in $\mathrm{CDCl}_{3}$.

\section{2. pH Titration Procedure}

Titration was carried out using a custom-built autotitrator. Place a magnetic stirring bar in the beaker and set the beaker over a magnetic stirrer. An appropriate amount of EDTA acid $(1.0 \mathrm{mmol})$ was dissolved in $20 \mathrm{~mL}$ of water. $\mathrm{Im}$ merse the electrodes in the solution and start the stirring. 0.1 M [BMIM] [OH] solution was added by a peristaltic pump (Shanghai $\mathrm{Hu} \mathrm{Xi}$ analysis instrument 
factory Co., Ltd., model HL-2) running at $1.0 \mathrm{~mL} \cdot \mathrm{min}^{-1}$. The $\mathrm{pH}$ of the mixture was recorded with a pH meter (ORION, model 828) interfaced to a computer.

\subsection{Synthesis of EDTA IL Buffer}

An aqueous solution of 1-buthyl-3-methyl-imidazolium hydroxide ([BMIM]OH) was prepared by passing [BMIM]Cl solution through a column filled with anion exchange resin, as described in the literature [2] [11]. The aqueous [BMIM]OH solution was then neutralized with EDTA acid in a beaker and the $\mathrm{pH}$ of the solution was adjusted to $3.90,6.50,8.50$ or 9.80 . The solution was evaporated at $50^{\circ} \mathrm{C}$ under reduced pressure to give a viscous liquid, which was then vacuum dried at $50^{\circ} \mathrm{C}$ for $18 \mathrm{~h}$ to afford EDTA IL buffer. NMR spectra of EDTA IL buffer: pH $9.80{ }^{1} \mathrm{H}$ NMR $\left(400 \mathrm{MHz}, \mathrm{D}_{2} \mathrm{O}\right) \delta: 7.368$ (s, 4H, im-H), $7.320(\mathrm{~s}, 4 \mathrm{H}$, im-H), 4.088 (t, $8 \mathrm{H},-\mathrm{CH}_{2}$ ), 3.784 (s, $\left.12 \mathrm{H}, \mathrm{im}-\mathrm{CH}_{3}\right), 3.447$ (s, $\left.8 \mathrm{H}, \mathrm{N}-\mathrm{CH}_{2}-\mathrm{COO}-\right)$, $3.033\left(\mathrm{~s}, 4 \mathrm{H}, \mathrm{N}-\mathrm{CH}_{2}-\mathrm{CH}_{2}-\mathrm{N}\right), 1.721-1.758\left(\mathrm{~m}, 8 \mathrm{H},-\mathrm{CH}_{2}\right), 1.199-1.217(\mathrm{~m}, 8 \mathrm{H}$, $\left.-\mathrm{CH}_{2}\right), 0.794-0.831\left(\mathrm{t}, 12 \mathrm{H},-\mathrm{CH}_{3}\right) ;{ }^{13} \mathrm{C} \mathrm{NMR}\left(400 \mathrm{MHz}, \mathrm{D}_{2} \mathrm{O}\right) \delta: 175.703$, $135.599,123.385,122.119,57.238,51.069,49.200,35.547,31.212,18.706,12.600$. pH $3.90{ }^{1} \mathrm{H}$ NMR (400 MHz, $\left.\mathrm{D}_{2} \mathrm{O}\right) \delta: 8.067$ (s, 2H, im-H), 7.368 (s, 2H, im-H), $7.328(\mathrm{~s}, 2 \mathrm{H}, \mathrm{im}-\mathrm{H}), 4.085\left(\mathrm{t}, 4 \mathrm{H},-\mathrm{CH}_{2}\right), 3.796\left(\mathrm{~s}, 6 \mathrm{H}, \mathrm{im}-\mathrm{CH}_{3}\right), 3.782(\mathrm{~s}, 8 \mathrm{H}$, $\left.\mathrm{N}-\mathrm{CH}_{2}-\mathrm{COO}-\right)$, 3.580 (s, 4H, N-CH$\left.-\mathrm{CH}_{2}-\mathrm{N}\right), 1.717-1.754\left(\mathrm{~m}, 4 \mathrm{H},-\mathrm{CH}_{2}\right), 1.195$ - $1.214\left(\mathrm{~m}, 4 \mathrm{H},-\mathrm{CH}_{2}\right), 0.790$ - $0.827\left(\mathrm{t}, 6 \mathrm{H},-\mathrm{CH}_{3}\right) ;{ }^{13} \mathrm{C}$ NMR $\left(400 \mathrm{MHz}, \mathrm{D}_{2} \mathrm{O}\right) \delta$ : $170.500,135.822,123.4495,122.169,57.939,51.569,49.232,35.602,31.235$, $18.721,12.624$.

\subsection{General Procedures of Enzymatic Transesterification in IL}

CALB $\left(1.2 \mathrm{mg}\right.$ ) was dissolved in $500 \mu \mathrm{L}$ of $\left[\mathrm{C}_{2} \mathrm{OHMIM}\right.$ [ $\left.\mathrm{BF}_{4}\right]$ (30 mg of EDTA IL buffer was added in the case of buffered medium) in a $5 \mathrm{~mL}$ flask. $110 \mu \mathrm{L}(0.83$ mmol) ethyl butyrate and $110 \mu \mathrm{L}(1.21 \mathrm{mmol}) n$-butanol and $50 \mu \mathrm{L}$ nonane (internal standard) were added. The reaction mixture was stirred at $40^{\circ} \mathrm{C}$ in oil bath for $3 \mathrm{~h}$. After the reaction was complete, the products was decanted from $\left[\mathrm{C}_{2} \mathrm{OHMIM}\right]\left[\mathrm{BF}_{4}\right]$. The organic phase was analyzed with a gas chromatograph equipped with an FID and a capillary column (SE-30, $30 \mathrm{~m} \times 0.32 \mathrm{~mm} \times 0.25$ $\mu \mathrm{m})$. The residual reactant mixture in IL phase was removed in vacuum at $40^{\circ} \mathrm{C}$ for more than $1 \mathrm{~h}$. The new cycle was restarted by addition of fresh substrate.

\subsection{HRP activity in Mercury Containing Aqueous System}

HRP activity was measured by following the $\mathrm{H}_{2} \mathrm{O}_{2}$-dependent oxidation of guaiacol at $470 \mathrm{~nm}$. Guaiacol stock solutions $(1.0 \mathrm{mM})$ were prepared by dissolving guaiacol in $0.1 \mathrm{M}$ buffer. For assays done in the presence of $\mathrm{Hg}^{2+}$ ions, appropriate amounts of $\mathrm{Hg}\left(\mathrm{NO}_{3}\right)_{2}$ stock solution were mixed with $0.1 \mathrm{M}$ buffer and the $\mathrm{pH}$ was readjusted whenever required. $\mathrm{H}_{2} \mathrm{O}_{2}$ stock solutions $(300 \mathrm{mM})$ were prepared daily by appropriate dilution of $30 \% \mathrm{H}_{2} \mathrm{O}_{2}$ in distilled water. HRP solutions $(10 \mu \mathrm{g} / \mathrm{ml})$ were prepared by dissolving the enzyme in distilled water. The assay was performed by mixing $500 \mu \mathrm{L}$ guaiacol stock solutions with $15 \mu \mathrm{L}$ 
of HRP solution (final concentration $7.8 \mathrm{nM}$ ) and the mixture was then incubated at $298 \mathrm{~K}$ for $30 \mathrm{~min}$. The reaction was started by adding $15 \mu \mathrm{L}$ of $300 \mathrm{mM}$ $\mathrm{H}_{2} \mathrm{O}_{2}$. The initial velocity $\left(\mathrm{v}_{0}\right)$ of the oxidation of guaiacol was determined from linear plotting of the absorbance versus time, using an extinction coefficient of $2.66 \times 10^{4} \mathrm{M}^{-1} \cdot \mathrm{cm}^{-1}$ for guaiacol-derived oxidation product.

All assays were carried out at $298 \mathrm{~K}$ using a UV-Vis spectrophotometer (Unico, UV2800) which cell was connected to a thermostat.

\section{Results and Discussion}

\subsection{Titration Profiles of EDTA}

The titration profile of EDTA with [BMIM]OH in water expressed 3 buffering-like regions, which are centered at $\mathrm{pH} 3.90,6.50$ and 8.50, respectively (Figure 1).

Thus, we considered that it is possible to synthesize new ILs of buffering ability by neutralization of aqueous solutions of [BMIM]OH with aqueous solutions of EDTA at pH 3.90, 6.50 and 8.50, as illustrated in Scheme 1.

\subsection{Synthesis and Characterization of EDTA IL Buffer}

The structure of EDTA IL buffers were shown in Scheme 1. The IL buffers were synthesized as previously reported [2] [11] and characterized by NMR. The characterization data of EDTA IL at $\mathrm{pH} 3.90$ and $\mathrm{pH} 9.80$ are consistent with the expected compositions and structures. The $\mathrm{pH}$, the dilution value, and buffer values of EDTA IL buffers were summarized in Table 1 . It can be seen that the ILs synthesized possess buffering ability and can be used for controlling the ionization of enzymes in both aqueous and non-aqueous media.

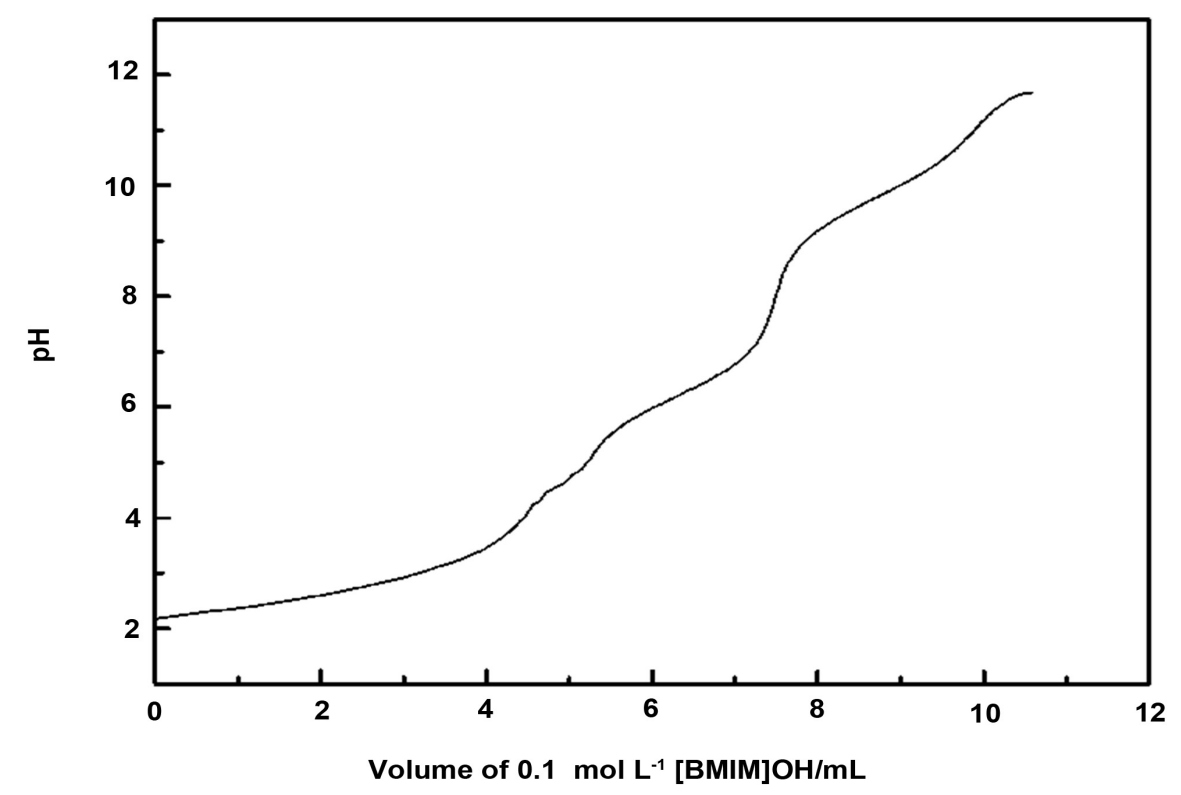

Figure 1. Titration for $0.05 \mathrm{~mol} \cdot \mathrm{L}^{-1}$ EDTA versus $0.1 \mathrm{~mol} \cdot \mathrm{L}^{-1}[\mathrm{BMIM}] \mathrm{OH}$ in water at room temperature. Titration rate is $1.0 \mathrm{~mL} \cdot \mathrm{min}^{-1}$. 


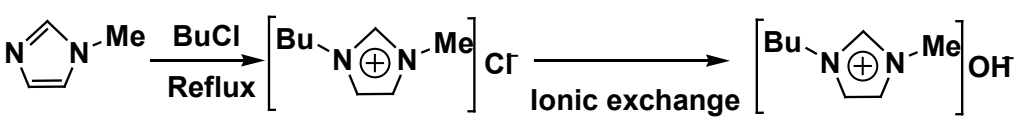

[BMIM]OH

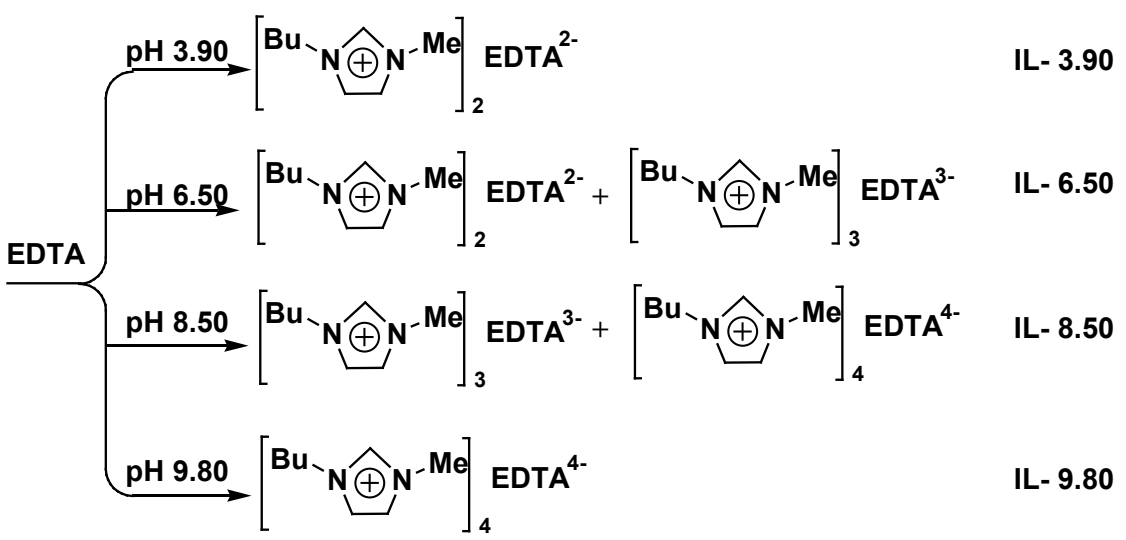

EDTA IL buffer

Scheme 1. Synthesis of EDTA IL buffer.

Table 1. pH, buffer values, and dilution values of the aqueous solution of EDTA IL buffers.

\begin{tabular}{ccccc}
\hline Buffer & $\mathrm{pH}$ & Concentration $/ \mathrm{mol} \cdot \mathrm{L}^{-1}$ & Dilution value $^{\mathrm{a})}$ & Buffer value $^{\mathrm{b})}$ \\
\hline IL- 3.90 & 3.90 & 0.025 & +0.01 & 0.004 \\
IL- 6.50 & 6.50 & 0.025 & +0.03 & 0.011 \\
IL- 8.50 & 8.50 & 0.025 & +0.03 & 0.002 \\
\hline
\end{tabular}

The structure of EDTA IL buffers, [BMIM $]^{+}[\text {EDTA }]^{\text {n- }}$ were shown in Scheme 1. The parameters were measured at room temperature. a Dilution value is defined as the change of $\mathrm{pH}$ on dilution with an equal volume of water. ${ }^{\text {b}}$ The buffer value is defined as the number of moles of strong base required to change the $\mathrm{pH}$ of one liter of solution by one unit.

\subsection{Enzymatic Transesterification in the Presence of EDTA IL Buffer}

Lipase-mediated transesterification is one of the economically viable clean technology for flavor ester production [29]. To test the activity of CALB lipase in dissolved form in ILs, we examined the CALB-catalyzed transesterification of ethyl butyrate with $n$-butanol. All the reactions were performed under the same conditions, $40^{\circ} \mathrm{C}$ and $300 \mathrm{rpm}$, in this study to eliminate any temperature or mixing effects. The results showed that CALB afforded lower substrate conversion in pure $\left[\mathrm{C}_{2} \mathrm{OHMIM}\right]\left[\mathrm{BF}_{4}\right](8.7 \%)$. In contrast, CALB exhibited great transesterification activity in the buffered $\left[\mathrm{C}_{2} \mathrm{OHMIM}\right]\left[\mathrm{BF}_{4}\right]$ (see Figure 2), indicating that the buffer was responsible for the rate enhancement.

The above results showed that the lipase activity is greatly affected by the IL and IL buffer. This is because the ionization constant of ionizable groups of the lipase is greatly affected by the solvent [30]. Thomazeau et al. reported that the acid $\mathrm{HNTf}_{2}$ is more acidic in $[\mathrm{BMIM}]\left[\mathrm{NTf}_{2}\right]$ and $[\mathrm{BMIM}]\left[\mathrm{BF}_{4}\right]$ than in water 


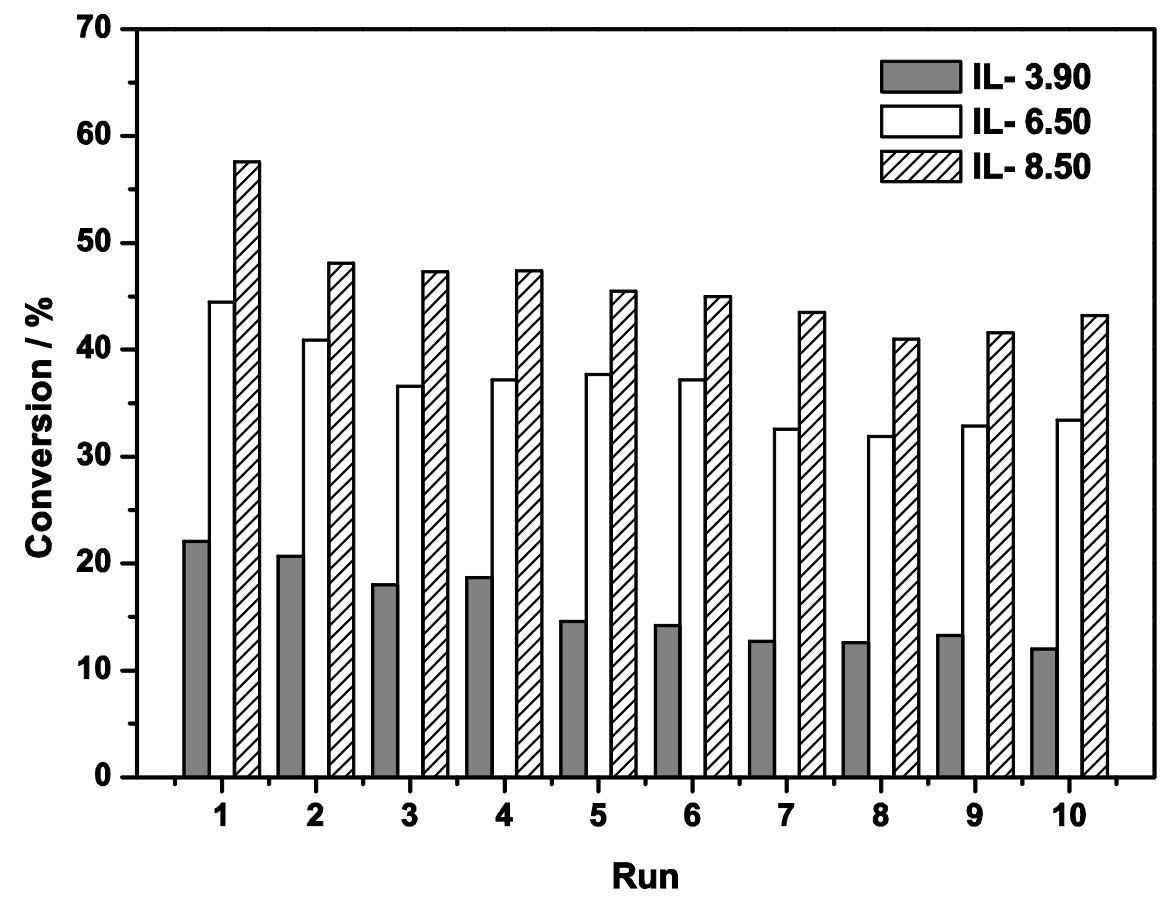

Figure 2. Transesterification of ethyl butyrate with 1-butanol catalyzed by CALB in buffered ILs. Reaction conditions: CALB powder $1.2 \mathrm{mg} ; 500 \mu \mathrm{L}$ of $\left[\mathrm{C}_{2} \mathrm{OHMIM}\right]\left[\mathrm{BF}_{4}\right] ; 30 \mathrm{mg}$ of EDTA IL buffer; $110 \mu \mathrm{L}$ of ethyl butyrate $(0.83 \mathrm{mmol}) ; 110 \mu \mathrm{L}$ of 1-butanol $(1.21$ $\mathrm{mmol}$ ); $50 \mu \mathrm{L}$ nonane (internal standard); stirring speed $=300 \mathrm{rpm}$; temperature $=40^{\circ} \mathrm{C}$. The conversion was calculated by ethyl butyrate.

[31]. Thus, when CALB transfer from water to $\left[\mathrm{C}_{2} \mathrm{OHMIM}\right]\left[\mathrm{BF}_{4}\right]$, the ionization state of the lipase will be changed, resulting in decrease of lipase activity. And addition of EDTA IL buffer can regulate the ionization state of ionizable groups of the lipase to the appropriate state. One can conclude that enzyme activity in ILs is also buffer dependent as in aqueous systems.

The recycling ability of the soluble CALB in buffered $\left[\mathrm{C}_{2} \mathrm{OHMIM}\right]\left[\mathrm{BF}_{4}\right]$ under the above reaction conditions is illustrated in Figure 2. After each reaction, the reactant mixture in the upper layer and CALB-IL in the lower layer were separated by decantation. The CALB-IL phase was then evacuated to remove residual reactant mixture and charged for the next reaction without adding any new enzyme, IL, and buffer. The lipase activity dropped significantly during recycling in the presence of EDTA IL buffer of $\mathrm{pH} 3.90$, suggesting that the lipase was gradually denatured in the acidic environment. However, the conversion of ethyl butyrate can maintain $75 \%$ of its initial value after 10 runs in the presence of EDTA IL buffer of $\mathrm{pH} 6.50$ or $\mathrm{pH} 8.50$, indicating that the dissolved CALB in the above buffered $\left[\mathrm{C}_{2} \mathrm{OHMIM}\right]\left[\mathrm{BF}_{4}\right]$ is very stable.

\subsection{HRP Activity in Mercury Containing Aqueous System}

Oxidative stress causes uncontrolled oxidation, resulting in the progressive deterioration and the collapse of organs and systems in the living organisms [32]. Peroxidases are important detoxifying enzymes serving to rid cells of excess 


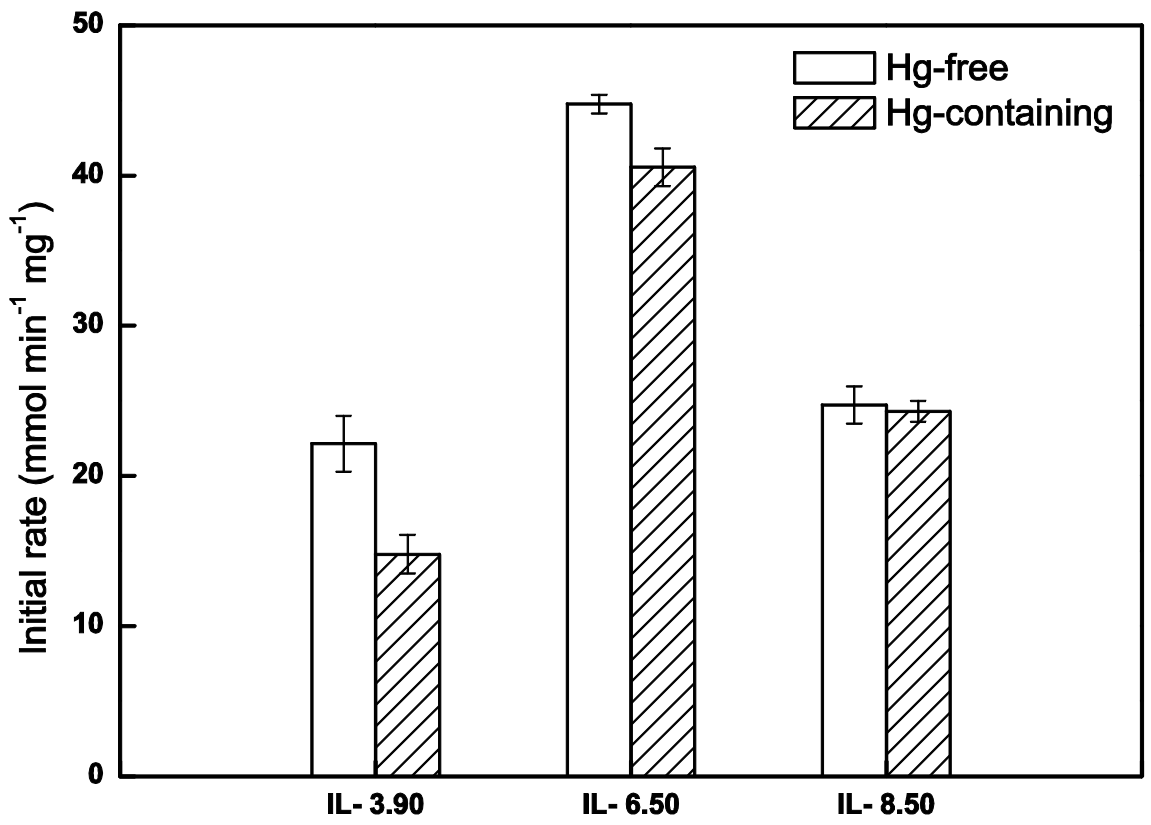

Figure 3. $\mathrm{Hg}^{2+}$ effect on HRP activity in EDTA IL buffer system. [HRP] $=7.8 \mathrm{nM}$ and $\left[\mathrm{Hg}^{2+}\right]=6.0 \mathrm{mM} .500 \mu \mathrm{L}$ guaiacol solution $(1.0 \mathrm{mM}) ; 5 \mu \mathrm{L} \mathrm{H}_{2} \mathrm{O}_{2}(300 \mathrm{mM})$; temperature, $298 \mathrm{~K}$. The initial velocity $\left(\mathrm{v}_{0}\right)$ of the oxidation of guaiacol was determined from linear plotting of the absorbance versus time, using an extinction coefficient of $2.66 \times 10^{4}$ $\mathrm{M}^{-1} \cdot \mathrm{cm}^{-1}$ for guaiacol-derived oxidation product. The error bars represent the standard deviation of measurements.

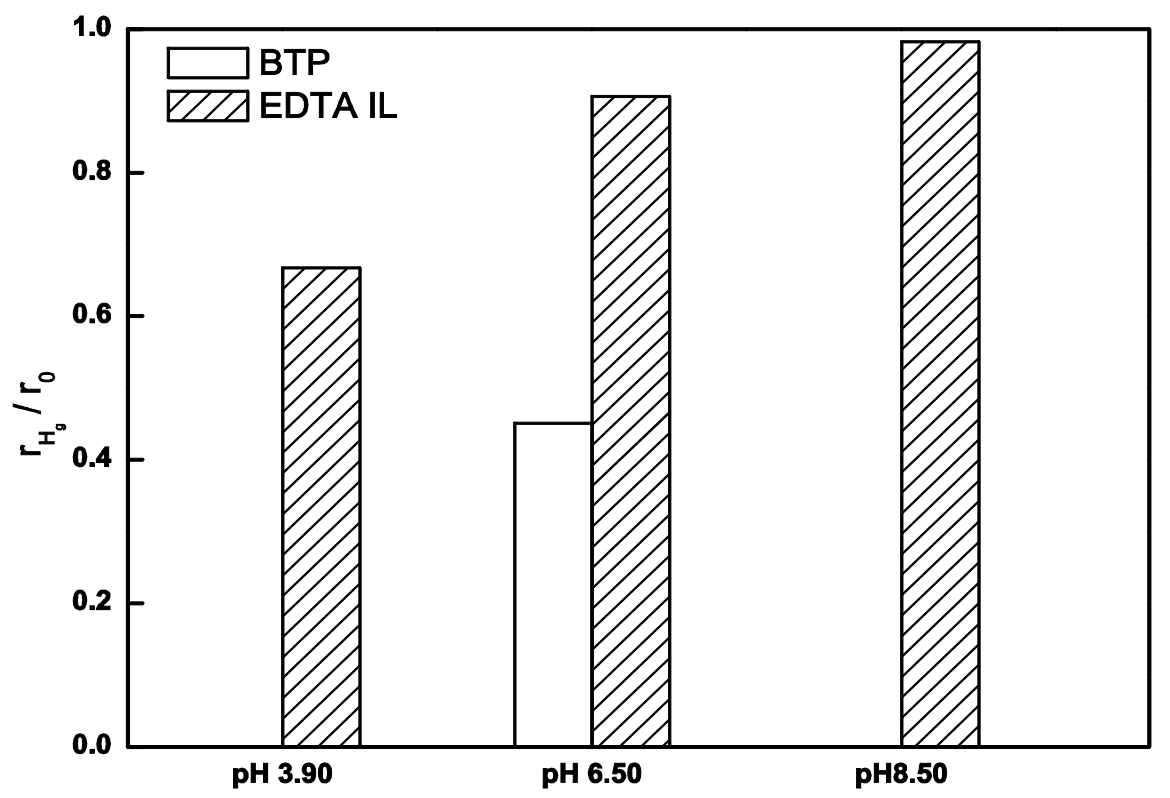

Figure 4. Comparison of $\mathrm{Hg}^{2+}$ effect on HRP activity in EDTA IL and BTP buffer systems. $[\mathrm{HRP}]=7.8 \mathrm{nM}$ and $\left[\mathrm{Hg}^{2+}\right]=6.0 \mathrm{mM} . \mathrm{r}_{0}$ and $\mathrm{r}_{\mathrm{Hg}}$ are the initial rate in $\mathrm{Hg}$ free and $\mathrm{Hg}$ containing systems, respectively.

$\mathrm{H}_{2} \mathrm{O}_{2}$, Horseradish peroxidase (HRP) is one of the best characterized peroxidases [33]. The effects of $\mathrm{Hg}^{2+}$ on HRP can be easily assayed through activity of $\mathrm{H}_{2} \mathrm{O}_{2}$-dependent oxidation, which can be assayed spectrophotometrically at 470 
nm using the $\mathrm{H}_{2} \mathrm{O}_{2}$-dependent oxidation of guaiacol.

Figure 3 showed that EDTA IL buffers as $\mathrm{Hg}^{2+}$ chelators protected HRP against $\mathrm{Hg}^{2+}$-induced denaturation and precipitation. Higher $\mathrm{pH}$ favored the protection, while at lower $\mathrm{pH}$ the protection diminished. Because the concentration of the deprotonated conjugate base of EDTA increases with the increase of $\mathrm{pH}$ of solution, its subsequent increased binding to $\mathrm{Hg}^{2+}$ causes the protection of $\mathrm{HRP}$ against $\mathrm{Hg}^{2+}$-induced denaturation. On the contrary, there is almost no $\mathrm{Hg}^{2+}$ chelators in BTP buffer system, thereby, $\mathrm{Hg}^{2+}$ inhibition occurs. This chelating effect undoubtedly explained the difference in Figure 3 and Figure 4.

\section{Conclusion}

In summary, ILs based on EDTA were synthesized by neutralization of [BMIM]OH with EDTA acid for the development of buffered enzymatic IL systems and for enzymatic reaction in heavy metal containing aqueous system. In buffered $\left[\mathrm{C}_{2} \mathrm{OHMIM}\right]\left[\mathrm{BF}_{4}\right]$, transesterification activity of CALB is buffer dependent and CALB is stable during recycles. In EDTA IL buffer aqueous system, EDTA as $\mathrm{Hg}^{2+}$ chelators protected HRP against $\mathrm{Hg}^{2+}$-induced denaturation and precipitation. Higher $\mathrm{pH}$ favored the protection, while at lower $\mathrm{pH}$ the protection diminished. We can conclude that the new ILs possess both buffering and chelating abilities and can be used for enzymatic applications.

\section{Data Availability}

The data used to support the findings of this study are included within the article.

\section{Acknowledgements}

We acknowledge the financial supports from the Natural Science Foundation of Fujian Province (2017J01635, 2019J01699), the Natural Science Foundation of China (41576085) and Fujian Provincial Key Laboratory of Food Microbiology and Enzyme Engineering (B18097-7).

\section{Conflicts of Interest}

The authors declare that there is no conflict of interest regarding the publication of this paper.

\section{References}

[1] Garcia-Viloca, M., Gao, J., Karplus, M. and Truhlar, D.G. (2004) How Enzymes Work: Analysis by Modern Rate Theory and Computer Simulations. Science, 303, 186-195. https://doi.org/10.1126/science.1088172

[2] Ou, G.N., Zhu, M.X., She, J.R. and Yuan, Y.Z. (2006) Ionic Liquid Buffers: A New Class of Chemicals with Potential for Controlling $\mathrm{pH}$ in Non-Aqueous Media. Chemical Communications, 44, 4626-4628. https://doi.org/10.1039/b611810k

[3] Xu, L., Ou, G.N. and Yuan, Y.Z. (2008) Ionic Liquids as Acid/Base Buffers in Non-Aqueous Solvents for Homogeneous Catalysis: A Case of Selective Hydrogena- 
tion of Olefins and Unsaturated Aldehyde Catalyzed by Ruthenium Complexes. Journal of Organometallic Chemistry, 693, 3000-3006. https://doi.org/10.1016/j.jorganchem.2008.06.028

[4] Ulbert, O., Frater, T., Belafi-Bako, K. and Gubicza, L. (2004) Enhanced Enantioselectivity of Candida rugosa Lipase in Ionic Liquids as Compared to Organic Solvents. Journal of Molecular Catalysis B-Enzymatic, 31, 39-45. https://doi.org/10.1016/j.molcatb.2004.07.003

[5] Laszlo, J.A. and Compton, D.L. (2002) Comparison of Peroxidase Activities of Hemin, Cytochrome $\mathrm{c}$ and Microperoxidase-11 in Molecular Solvents and Imidazolium-Based Ionic Liquids. Journal of Molecular Catalysis B-Enzymatic, 18, 109-120. https://doi.org/10.1016/S1381-1177(02)00074-7

[6] Klibanov, A.M. (2001) Improving Enzymes by Using Them in Organic Solvents. Nature, 409, 241-246. https://doi.org/10.1038/35051719

[7] Wescott, C.R. and Klibanov, A.M. (1994) The Solvent Dependence of Enzyme Specificity. Biochimica et Biophysica Acta-Protein Structure and Molecular Enzymology, 1206, 1-9. https://doi.org/10.1016/0167-4838(94)90065-5

[8] Sabally, K., Karboune, S., Yeboah, F.K. and Kermasha, S. (2005) Lipase-Catalyzed Esterification of Selected Phenolic Acids with Linolenyl Alcohols in Organic Solvent Media. Applied Biochemistry and Biotechnology, 127, 17-27. https://doi.org/10.1385/ABAB:127:1:017

[9] Akbari, N., Daneshjoo, S., Akbari, J. and Khajeh, K. (2011) Isolation, Characterization, and Catalytic Properties of a Novel Lipase Which Is Activated in Ionic Liquids and Organic Solvents. Applied Biochemistry and Biotechnology, 165, 785-794. https://doi.org/10.1007/s12010-011-9296-x

[10] Persson, M. and Bornscheuer, U.T. (2003) Increased Stability of an Esterase from Bacillus stearothermophilus in Ionic Liquids as Compared to Organic Solvents. Journal of Molecular Catalysis B-Enzymatic, 22, 21-27. https://doi.org/10.1016/S1381-1177(02)00294-1

[11] Ou, G.N., Yang, J., He, B.Y. and Yuan, Y.Z. (2011) Buffer-Mediated Activation of Candida antarctica Lipase B Dissolved in Hydroxyl-Functionalized Ionic Liquids. Journal of Molecular Catalysis B-Enzymatic, 68, 66-70.

https://doi.org/10.1016/j.molcatb.2010.09.013

[12] Ou, G.N., Xu, L., He, B.Y. and Yuan, Y.Z. (2008) Enhanced Stability of Charged Dendrimer-Encapsulated Pd Nanoparticles in Ionic Liquids. Chemical Communications, 35, 4210-4212. https://doi.org/10.1039/b806163g

[13] Kaar, J.L., Jesionowski, A.M., Berberich, J.A., Moulton, R. and Russell, A.J. (2003) Impact of Ionic Liquid Physical Properties on Lipase Activity and Stability. Journal of the American Chemical Society, 125, 4125-4131. https://doi.org/10.1021/ja028557x

[14] Ou, G.N., He, B.Y. and Halling, P. (2016) Ionization Basis for Activation of Enzymes Soluble in Ionic Liquids. Biochimica et Biophysica Acta-General Subjects, 1860, 1404-1408. https://doi.org/10.1016/j.bbagen.2016.04.004

[15] Zhao, H. (2005) Effect of Ions and Other Compatible Solutes on Enzyme Activity, and Its Implication for Biocatalysis Using Ionic Liquids. Journal of Molecular Catalysis B-Enzymatic, 37, 16-25. https://doi.org/10.1016/j.molcatb.2005.08.007

[16] Habulin, M. and Knez, Z. (2009) Optimization of (R,S)-1-Phenylethanol Kinetic Resolution over Candida antarctica Lipase B in Ionic Liquids. Journal of Molecular Catalysis B-Enzymatic, 58, 24-28. https://doi.org/10.1016/j.molcatb.2008.10.007 
[17] Vidya, P. and Chadha, A. (2009) The Role of Different Anions in Ionic Liquids on Pseudomonas cepacia Lipase Catalyzed Transesterification and Hydrolysis. Journal of Molecular Catalysis B-Enzymatic, 57, 145-148. https://doi.org/10.1016/j.molcatb.2008.08.007

[18] Janati-Fard, F., Housaindokht, M.R., Monhemi, H., Esmaeili, A.A. and Pour, A.N. (2018) The Influence of Two Imidazolium-Based Ionic Liquids on the Structure and Activity of Glucose Oxidase: Experimental and Theoretical Studies. International Journal of Biological Macromolecules, 114, 656-665. https://doi.org/10.1016/j.ijbiomac.2018.03.083

[19] Yamamoto, E., Yamaguchi, S. and Nagamune, T. (2011) Protein Refolding by N-Alkylpyridinium and N-Alkyl-N-Methylpyrrolidinium Ionic Liquids. Applied Biochemistry and Biotechnology, 164, 957-967. https://doi.org/10.1007/s12010-011-9187-1

[20] He, B.Y., Ou, G.N., Zhou, C.Y., Wang, M.H. and Chen, S.Y. (2013) Antimicrobial Ionic Liquids with Fumarate Anion. Journal of Chemistry, 2013, Article ID: 473153.

[21] Torralba-Calleja, E., Skinner, J. and Gutierrez-Tauste, D. (2013) $\mathrm{CO}_{2}$ Capture in Ionic Liquids: A Review of Solubilities and Experimental Methods. Journal of Chemistry, 2013, Article ID: 473584. https://doi.org/10.1155/2013/473584

[22] Perez de los Rios, A., Irabien, A., Hollmann, F. and Hernandez Fernandez, F.J. (2013) Ionic Liquids: Green Solvents for Chemical Processing. Journal of Chemistry, 2013, Article ID: 402172.

[23] Stratton, A., Ericksen, M., Harris, T.V., Symmonds, N. and Silverstein, T.P. (2017) Mercury(II) Binds to Both of Chymotrypsin's Histidines, Causing Inhibition Followed by Irreversible Denaturation/Aggregation. Protein Science, 26, 292-305. https://doi.org/10.1002/pro.3082

[24] Krajewska, B. (2008) Mono-(Ag, Hg) and Di-(Cu, Hg) Valent Metal Ions Effects on the Activity of Jack Bean Urease. Probing the Modes of Metal Binding to the Enzyme. Journal of Enzyme Inhibition and Medicinal Chemistry, 23, 535-542. https://doi.org/10.1080/14756360701743051

[25] Keyhani, J., Keyhani, E., Einollahi, N., Minai-Tehrani, D. and Zarchipour, S. (2003) Heterogeneous Inhibition of Horseradish Peroxidase Activity by Cadmium. Biochimica et Biophysica Acta-General Subjects, 1621, 140-148. https://doi.org/10.1016/S0304-4165(03)00053-9

[26] Carvalho, C.M.L., Chew, E.-H., Hashemy, S.I., Lu, J. and Holmgren, A. (2008) Inhibition of the Human Thioredoxin System-A Molecular Mechanism of Mercury Toxicity. Journal of Biological Chemistry, 283, 11913-11923. https://doi.org/10.1074/jbc.M710133200

[27] Branco, V., Canario, J., Lu, J., Holmgren, A. and Carvalho, C. (2012) Mercury and Selenium Interaction in Vivo: Effects on Thioredoxin Reductase and Glutathione Peroxidase. Free Radical Biology and Medicine, 52, 781-793. https://doi.org/10.1016/j.freeradbiomed.2011.12.002

[28] Myshkin, A.E. and Khromova, V.S. (2005) A New Insight into Mercurized Hemoglobin Aggregation Mechanism. Biochimica et Biophysica Acta-Proteins and Proteomics, 1749, 1-6. https://doi.org/10.1016/j.bbapap.2005.01.008

[29] Garlapati, V.K., Kumari, A., Mahapatra, P. and Banerjee, R. (2013) Modeling, Simulation, and Kinetic Studies of Solvent-Free Biosynthesis of Benzyl Acetate. Journal of Chemistry, 2013, Article ID: 451652. https://doi.org/10.1155/2013/451652

[30] Frey, P.A., Whitt, S.A. and Tobin, J.B. (1994) A Low-Barrier Hydrogen-Bond in the Catalytic Triad of Serine Proteases. Science, 264, 1927-1930. 
https://doi.org/10.1126/science.7661899

[31] Thomazeau, C., Olivier-Bourbigou, H., Magna, L., Luts, S. and Gilbert, B. (2003) Determination of an Acidic Scale in Room Temperature Ionic Liquids. Journal of the American Chemical Society, 125, 5264-5265. https://doi.org/10.1021/ja0297382

[32] Ostojic, J., Herenda, S., Galijasevic, S., Galic, B. and Milos, M. (2017) Inhibition of Horseradish Peroxidase Activity by Boroxine Derivative, Dipotassium-Trioxohydroxytetrafluorotriborate $\mathrm{K}-2\left[\mathrm{~B}_{3} \mathrm{O}_{3} \mathrm{~F}_{4} \mathrm{OH}\right]$. Journal of Chemistry, 2017, Article ID: 8134350.

[33] Song, H.-Y., Liu, J.-Z., Weng, L.-P. and Ji, L.-N. (2009) Activity, Stability, and Unfolding of Reconstituted Horseradish Peroxidase with Modified Heme. Journal of Molecular Catalysis B-Enzymatic, 57, 48-54.

https://doi.org/10.1016/j.molcatb.2008.06.015 